\title{
PRETO VELHO ME CONTOU: TECENDO OS FIOS QUE CONSTROEM AS REPRESENTAÇÕES DO ESCRAVIZADO IDOSO
}

\author{
OLD BLACK TALES: WEAVING THE THREADS THAT FRAME OLD \\ ENSLAVED REPRESENTATIONS
}

Livia Lima Rezende $e^{1}$

RESUMO: O artigo se propõe a explorar as distintas representações dos escravizados idosos nos cenários do pós-abolição Afro-Latino-Americano, tendo como fio condutor três características definidoras dessas figuras, quais sejam: a relevância da oralidade e do ato de narrar histórias; o tratamento familiar que lhes é dirigido; e os processos de elaboração religiosa associados a elas. Os pressupostos teóricos são oferecidos por conceitos como o de memória cultural e monumentalização, enquanto instrumentaliza-se a história oral e a vivência de campo como principais metodologias de pesquisa. Foi possível notar que, a despeito da relativa estabilidade em sua representação, percebem-se transformações na forma como esse personagem é política e socialmente apropriado, tornando-se cada vez mais um exemplo de resistência pacífica e força libertária.

PALAVRAS-CHAVE: preto-velho; umbanda; memória da escravidão; Pai João; memória cultural.

ABSTRACT: The article aims to explore the different images and representations of the elderly enslaved in the Afro-Latin-America post-abolition scenarios, having as guiding thread three defining characteristics of these figures: the relevance of orality and the act of telling stories; the family treatment addressed to them; and their religiosity, which brings together some African and American elements. In spite of this relative stability in its representation, it was possible to perceive transformations in the way this personage is politically and socially appropriate, becoming more and more an example of peaceful resistance and libertarian force.

\footnotetext{
* Pesquisa decorrente de tese de doutorado desenvolvida junto ao Programa de Pós-graduação em História da Universidade Federal de Juiz de Fora, com financiamento da CAPES (Coordenação de Aperfeiçoamento de Pessoal de Nível Superior).

1 Doutoranda em História pela Universidade Federal de Juiz de Fora (UFJF). Email: livialimar@gmail.com
} 
KEYWORDS: old black; Umbanda; slavery memory; Uncle Tom; cultural memory.

E como lidar com uma memória ora viva, ora esfacelada? Surgiu então o invento para cobrir os vazios de lembranças transfiguradas.

Conceição Evaristo - Becos da Memória

A figura do negro idoso, contador de "causos" e conhecedor de "mandigas" permeia o imaginário popular de diversos países cujo presente se arrima num longo passado escravista. A despeito da distância física, personagens como o Pai Tomás norte-americano, a Mãe Maria e o Pai João do folclore brasileiro, ou a mama vieja uruguaia guardam semelhanças que nos permitem tratar de uma memória coletiva da escravidão elaborada cotidianamente em nível continental. Sempre associados a escravizados idosos, esses pretos velhos se apresentam como um excelente instrumento para o estudo e melhor entendimento das formas como a cultura popular foi se apropriando e interpretando as memórias do cativeiro.

Tendo como base as duas características mais óbvias de sua caracterização, derivadas diretamente da alcunha que usualmente recebem: pretos (associado à cor de sua pele) e velhos (denotando uma condição vinculada ao tempo de vida), convidamos o leitor a nos acompanhar em uma imersão nas dimensões cultural, histórica e social dessas figuras. Pretendemos perscrutar neste artigo alguns dos atributos que permeiam a construção desses personagens em searas tão diversas quanto a literatura, o carnaval, o folclore e a religião. Para tanto, estruturamos nosso estudo seguindo três eixos primordiais: a relevância das narrativas na construção dessas figuras, o tratamento familiar que lhes é dirigido e os processos de elaboração religiosa associados a eles.

Sobre a arte de narrar e as palavras andarilhas

Segundo uma definição bastante superficial, ainda que extremamente prática, do clássico dicionário Aurélio, arte é a "capacidade que tem o homem 
de, dominando a matéria, pôr em prática uma ideia". Ela também pode ser entendida, segundo a mesma fonte, como "habilidade" ou "ofício". Propomonos aqui a compreender matéria para além de seu sentido físico, transbordando sua acepção de modo a englobar algo mais abstrato. Isso posto, é possível descrever a "arte de narrar" como a faculdade ou a aptidão que uma pessoa possui de transmitir experiências a partir do domínio de duas matérias principais: a linguagem -sobretudo oral- e a memória. Narramos aquilo que recordamos haver vivido no decorrer de uma existência, bem como experiências alheias que nos foram contadas e das quais nos lembramos.

Walter Benjamim (1994) menciona que a figura do narrador só se tornaria plenamente tangível a partir da conjunção de duas vivências: a granjeada a partir de longas viagens e aquela conquistada após longo período de estadia em um mesmo contexto, permitindo vasto conhecimento acerca de suas histórias e tradições. Seria o encontro entre os saberes das terras distantes e os saberes locais. Tal configuração permitiria a construção de uma narrativa com desdobramentos mais funcionais -ou úteis-, isto é, baseada em um ensinamento moral ou numa sugestão prática acerca de algo.

Impossível dissociar essa arte do narrar da figura dos escravizados idosos que povoam o imaginário popular, sobretudo se relacionarmos o acúmulo de experiências de vida ao avanço da idade e às mais diversas situações a que teriam sido submetidos sob uma conjuntura escravista. Pode-se afirmar, com segurança, que os pretos velhos da cultura popular são exemplos clássicos de narradores no sentido proposto por Benjamim. Conforme mencionado por Pollard (1981: 228, tradução nossa): "Eles [escravizados idosos] eram contadores de histórias, conselheiros, o vínculo estabelecido entre presente e passado, e os historiadores de um povo não-letrado"

Os contos de pai João e mãe Maria do folclore brasileiro, por exemplo, apresentam uma dupla dimensão da arte de narrar. Num primeiro plano, ambos os personagens são construídos a partir das histórias que contam acerca de suas

\footnotetext{
${ }^{2}$ They were the storytellers, the advisors, the links between the past and present, and the historians of a non-literate people.
} 
vivências num contexto africano e, posteriormente, brasileiro (tal como defendido por Benjamim - 1994 -, há o somatório das experiências numa terra distante àquelas arroladas durante os anos de cativeiro). Num segundo foco de análise, tem-se o desdobramento, típico dos contos folclóricos, em que as próprias narrativas de Pai João e Mãe Maria passam a ser recontadas pela população em geral. Transcrevemos a seguir trechos de uma das canções associadas ao Pai João:

Quando iô tava na minha tera

Iô chamava capitão,

Chega em tera dim baranco, Iô me chama - Pai João.

Quando iô tava na minha tera

Comia minha garinha,

Chega na terá dim baranco,

Cáne sêca co farinha

[...] Dizofôro dim baranco

Nô si póri aturá,

Tá comendo, tá... drumindo,

Manda negro trabaiá.

[...] Baranco dize - preto fruta,

Preto fruta co rezão;

Sinhô baranco também fruta

Quando panha casião.

Nosso preto fruta garinha

Fruta sacco de fuijão;

Sinhô baranco quando fruta

Fruta prata e patacão.

Nosso preto quando fruta

Vai pará na correção,

Sinhô baranco quando fruta,

Logo sai sinhô barão ${ }^{3}$

O trecho demonstra claramente a capacidade que o narrador possui de expor, de maneira direta e prática, parte de suas experiências de vida. Tanto a

\footnotetext{
${ }^{3}$ Mendes, Canções populares do Brasil apud ABREU, 2004: 245.
} 
linguagem quanto a memória de que tratamos anteriormente também podem ser elucidadas por este exemplo. Ao mencionarmos o domínio da primeira como requisito para a arte de narrar, não exprimimos o imperativo do conhecimento das normas cultas. A habilidade de Pai João em se expressar através de um português coloquial facilita, em muitos casos, a internalização da mensagem transmitida e a memorização dos contos e canções por quem as escuta ${ }^{4}$.

Cabe destacar ainda a concisão da narrativa e sua renúncia a análises psicológicas muito aprofundadas. Pai João vai, de maneira direta e objetiva, pontuando as situações e experiências. Retomando novamente Benjamim:

Quanto maior a naturalidade com que o narrador renuncia às sutilezas psicológicas, mais facilmente a história se gravará na memória do ouvinte, mais completamente ela se assimilará à sua própria experiência e mais irresistivelmente ele cederá à inclinação de recontá-la um dia (1994: 204).

Há, nesse tipo de narrativa, o interesse em sua conservação e replicação. Talvez por isso as histórias de Pai João remontem ao final do século XIX conforme apresentado por autores como Arthur Ramos (1935), Roger Bastide (1983) e Câmara Cascudo (1984) -, e permaneçam presentes até hoje.

Elegemos essa canção específica também por ser capaz de ilustrar de que forma a narrativa pode atuar na construção ou desconstrução de estereótipos. Nas palavras de Bastide (1983), de quem discordamos, Mãe Maria e Pai João seriam criações dos brancos, tendo como propósito justificar o regime escravista. Materializariam tipos ideais do "negro bom", escravo conformado e submisso, "pilares de uma raça resignada" (1983: 437-438).

Mais recentemente, Martha Abreu (2004, 2017) logrou sistematizar grande parte da bibliografia sobre Pai João ${ }^{5}$. Tendo como base cantigas, contos e poemas registrados por folcloristas entre 1880 e 1950 acerca desse personagem, a autora desconstrói o estereótipo que o apresenta como antítese de Zumbi -contrapondo, como dois polos opostos e excludentes, o escravo

\footnotetext{
${ }^{4}$ Sobre a linguagem de Pai João e dos pretos-velhos umbandistas ver Alkmin; López (2009) e Abreu (2017).

${ }^{5}$ É interessante notar também que embora "João" seja a alcunha comumente utilizada, a autora encontrou registros em Brandão (1949) de outros personagens com estilo semelhante, embora com nomes distintos: Pai Miguel, Pai José, entre outros (ABREU, 2004: 268).
} 
submisso e o revoltado ${ }^{6}$. Ela encontrou nos registros de diversos autores caracterizações aparentemente antagônicas acerca do Pai João (resignado x vingativo; lerdo x esperto; manso $\mathrm{x}$ astuto), demonstrando a complexidade do personagem e, de certa forma, sintetizando a multiplicidade da própria condição dos escravos e de seus descendentes e das formas como eram interpretados. Nas palavras de Abreu: “em torno do 'Folclore de Pai João' se verificam, em termos culturais e políticos, o conflito, a dominação, a subversão, a rebeldia e a negociação sobre papéis, identidades e possibilidades dos homens negros durante a escravidão e no período pós-emancipação" (2004: 238), conforme demonstrado na canção que apresentamos acima.

Outro aspecto da arte de narrar que merece ser destacado e que se relaciona diretamente a essa figura do escravizado idoso na cultura popular diz respeito à instrumentalização de experiências próprias ao aconselhamento, ou ao dar exemplo, numa terminologia mais popular. Segundo Benjamim: "O narrador é um homem que sabe dar conselhos. [...] Aconselhar é menos responder a uma pergunta que fazer uma sugestão sobre a continuação de uma história que está sendo narrada. [...] O conselho tecido na substância viva da existência tem um nome: sabedoria" (1994: 200). Os pretos velhos lançam mão de suas trajetórias de vida para oferecer sugestões e conselhos àqueles que os escutam e tem sua imagem normalmente associada à do ancião sábio.

Youssouf Tata Cissé, etnólogo e historiador malinês e grande pesquisador da literatura oral africana dizia que "a palavra não tem pernas, mas caminha" (CISSÉ apud OLAZA, 2009: 102, tradução nossa) ${ }^{7}$. As narrativas dos e sobre os pretos velhos no folclore e na literatura peregrinariam, alcançando os mais diversos campos e pessoas. E diríamos mais, ao marchar, as palavras proferidas por essas figuras esparziriam sementes de memórias ${ }^{8}$. Elas carregariam consigo enorme bagagem cultural e tradicional, que poderia ou não

\footnotetext{
${ }^{6}$ A autora retoma os questionamentos propostos por Eduardo Silva no livro Negociação e Conflito organizado por ele mesmo e Reis (1989).

${ }^{7}$ La palavra no tiene piernas pero camina.

${ }^{8}$ Essa noção de figuras ancestrais espalhando sementes de memórias por suas palavras e por seus gestos foi inicialmente sugerida por Julio, um afrodescendentes uruguaio entrevistado por Mónica Olaza (2009: 84).
} 
germinar ao ser escutada e novamente transmitida. Independentemente desse desabrochar da semente, é interessante notar o sentido atribuído por Julio ${ }^{9}$, afro uruguaio entrevistado por Olaza (2009), a esse ato de semear memórias. Ele menciona, retomando tradições iorubas e bantu, que "o povo que perde sua memória, perde o caminho de seu destino" (2009: 84, tradução nossa ${ }^{10}$ ), sendo assim, o caminhar dessas palavras atuaria de modo a criar noções de pertencimento e de identidade num sentido muito mais amplo.

A associação entre essas palavras caminhantes e a tomada de consciência de si, tendo em vista o trilhar de um caminho, expõe o intricado equilíbrio entre os tempos que é sustentado pelos pretos velhos. Para além de livros, canções e contos folclóricos, suas narrativas emergem ainda em âmbito muito particular: as famílias dos descendentes de escravizados. Embora não possuam a amplitude (ou a imprecisão) temporal e espacial de um Pai João, por exemplo, a figura do avô ou da avó numa família afrodescendente carrega consigo uma potência verdadeiramente impressionante. A presença desse ancião enquanto personagem guardião de uma sabedoria ancestral que deve ser transmitida através das narrativas aos mais novos aflora em entrevistas, músicas, poesias e imagens. Retornaremos à relevância dessa ancestralidade no próximo tópico. Voltemo-nos, por enquanto, à análise da imagem a seguir:

Figura 1

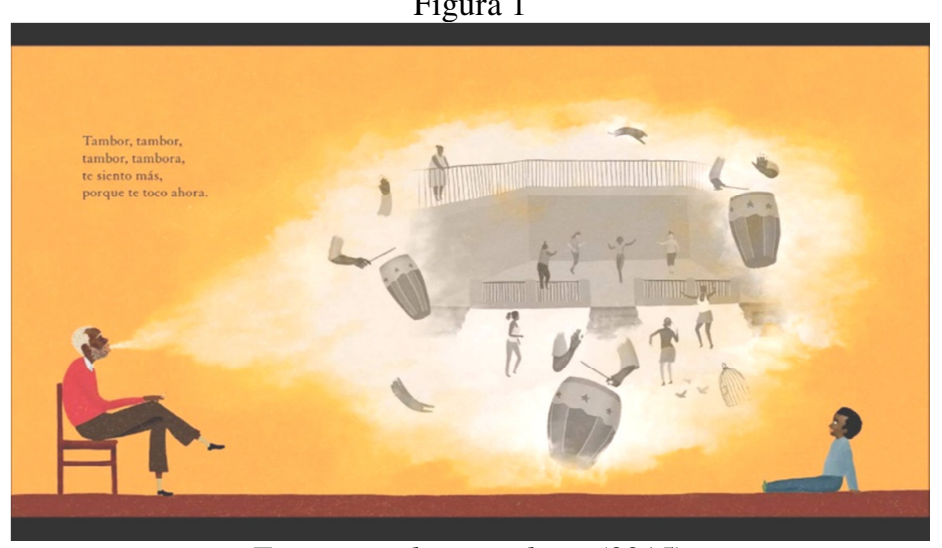

Fonte: Tambor Tambora (2015)

\footnotetext{
${ }^{9}$ Cabe mencionar que a autora não apresenta os sobrenomes dos entrevistados no livro, tampouco um resumo de suas histórias pessoais.

${ }^{10}$ [...] el pueblo que perde su memoria pierde el caminho de su destino.
} 
O desenho foi retirado do livro infantil Tambor Tambora. A obra ilustra a letra da música de mesmo nome do cantor uruguaio Jorginho Gularte. A canção é uma homenagem ao conventillo Medio Mundo, espécie de cortiço localizado no bairro Sur em Montevidéu. Nesse local viviam vários descendentes de escravizados da capital uruguaia, tendo sido demolido durante a ditadura militar para a construção de um condomínio de luxo -não sem forte resistência da comunidade ${ }^{11}$. Ainda hoje muitos grupos culturais e religiosos afro uruguaios se apresentam ou prestam sua reverência em frente ao número 1080 da rua Cuareim, onde outrora estava o conventillo. Para a população do bairro, o Medio Mundo teria sido um local de resistência, convivência e efervescência cultural entre os descendentes dos cativos. $O$ desenho apresenta a figura de um senhor negro, idoso, fumando seu cigarro com aparente tranquilidade diante de uma criança. Na fumaça do cachimbo aparecem imagens em preto e branco que remetem a um passado distante vivido no Medio Mundo, com tambores, dança e uma animada confraternização. A ilustração exibe de maneira extremamente didática e delicada a transmissão da experiência desse ancião aos mais novos, com o intuito de estabelecer um sentido de pertencimento e respeito por aquele espaço e suas tradições - muitas das quais se recriaram em outros locais na região ${ }^{12}$. São esses senhores os responsáveis por estabelecer elos entre o passado (com suas tradições e experiências), o presente (constantemente em construção através, principalmente, da oralidade) e o futuro (representado pela criança, com seus sonhos e expectativas).

Paralelos brasileiros da relevância dos anciãos e suas narrativas podem ser encontradas em expressões culturais e em entrevistas com famílias de

\footnotetext{
11 Durante visita a Montevidéu em março de 2018 realizamos diversas entrevistas com a comunidade afro-uruguaia. Absolutamente todos os entrevistados fazem algum tipo de referência ao episódio como uma forma de violência física e simbólica extremamente profunda contra essa parcela da sociedade.

${ }^{12}$ Embora estejamos centrando nossa análise na oralidade e na arte do narrar, faz-se necessário salientar que a transmissão, na ilustração em questão, é apresentada por meio da fumaça do cigarro do idoso negro. O fumo e a fumaça são elementos absolutamente essenciais na construção de um imaginário e uma memória africanas. Sobre o tema ver: SLENES (1999) e REZENDE (2107).
} 
escravizados. Iniciamos com um exemplo no campo da poesia, com VozesMulheres de Conceição Evaristo:

A voz de minha bisavó
ecoou criança
nos porões do navio.
ecoou lamentos
de uma infância perdida.

A voz de minha avó ecoou obediência aos brancos-donos de tudo.

A voz de minha mãe ecoou baixinho revolta no fundo das cozinhas alheias debaixo das trouxas roupagens sujas dos brancos pelo caminho empoeirado rumo à favela.

A minha voz ainda ecoa versos perplexos com rimas de sangue e fome.

A voz de minha filha recolhe todas as nossas vozes recolhe em si as vozes mudas caladas engasgadas nas gargantas.

A voz de minha filha recolhe em si a fala e o ato.

O ontem - o hoje - o agora.

$\mathrm{Na}$ voz de minha filha se fará ouvir a ressonância o eco da vida-liberdade.

Nota-se que o estabelecimento de pontes entre distintas temporalidades (ontem, hoje, agora e amanhã) se coloca por um único elemento: a voz. É ela quem permeia as vivências e ressoa conhecimento e resistência entre gerações. 
Há, ainda no caso brasileiro, vasta bibliografia que se dedica aos trabalhos de história oral com as famílias das últimas gerações de escravizados no país. A construção das memórias que emerge dos relatos é sempre impulsionada por relatos de antepassados idosos (com ou sem vínculo familiar direto) que relatavam as rotinas do tempo do cativeiro. Assunção (2011) analisou casos muito interessantes no Maranhão, muitos deles narrados a partir do conhecimento que os entrevistados estabeleceram com os denominados pretos velhos (descritos pelo pesquisador como senhores e senhoras de idade avançada que teriam sido escravizados na região). A fala da senhora Maria Garreto a seguir é um bom exemplo:

Uma preta velha me contou de quanto os senhores eram maus. Contava de uma feitoria no Veado Branco (município de Brejo), aí tinha um preto velho com os pés grande demais e não podia andar bem. O patrão que levantava tarde depois do frio, tomava banho, tomava café, pegava o cavalo para ir à roça ver os preto trabalhar e ainda alcançava ele no caminho. Aí surrava ele: 'Caminha! negro velho!' Ele: 'Não posso, senhor!' porque não podia. Mas o senhor surrava e depois cortava as nádegas e botava sal" (2011: 87, grifo nosso).

As entrevistas compiladas por Hebe Mattos e Ana Lugão Rios (2005), apresentam, em diversos momentos, essa referência ao avô ou avó narrador(a), como essas transcrições das entrevistas com a senhora Benedita, de São Paulo; M.O.B. do Espírito Santo; e D. Zeferina, do Rio de Janeiro, respectivamente:

Contavam os meus avós, que os avós deles vieram pegados da África. [...] Chegava de noite, no tempo do frio faziam fogo pra esquentar... Ficava tudo sentado assim em roda de fogo, ficava aquele mundo de netaiada de preto, e então aqueles avós, que tinham vindo da África, começavam a contar história da África (2005: 66, grifo nosso).

Os antigos contavam que a vida na época do cativeiro era prejudicada (2005: 70, grifo nosso).

Meu pai eu conheci muito, minha avó também conheci, e eles contavam histórias (2005: 90, grifo nosso).

No contexto específico de São João del-Rei realizei uma entrevista com o senhor Antônio Laurindo. Neto de escravizado, seu Antônio conta os casos do 
avô, senhor Laurindo Miguel da Costa, cativo na região de Volta Grande, Minas Gerais. Ele menciona que o avô tinha o costume de sentar-se com os netos ao redor de uma fogueira para contar os casos do tempo do cativeiro. Seu Antônio destaca as narrativas que ouviu acerca do Moçambique, negro idoso, "ventre-livre" que o avô teria conhecido no tempo do cativeiro:

Moçambique meu avó disse que era invisível, era um homem invisível. E esse Moçambique trabalha no santo ${ }^{13}$ hoje [...]. Moçambique, o misterioso. Tinha pena desses que já foram escravos, família, criança. [...] Ajudava os escravos fugidos ${ }^{14}$.

Em todas as situações narradas, a ancestralidade e a relevância da transmissão dos saberes através do contar revela uma dimensão coletiva das narrativas. Essas palavras andarilhas, que caminham por gerações, constituemse, em última instância, como guardiãs de uma memória coletiva -ainda que uma memória cotidianamente ressignificada à luz do contexto em que são narradas.

O entrelaçamento de tempos -passado, presente e futuro- que se estabelece mediante as narrativas de um preto velho, seja ele Pai João, Mãe Maria ou um bisavô escravizado carrega consigo uma dimensão afetiva do aprendizado inerente a essa arte de narrar. Conforme mencionado por Mia Couto (AULA, 2014), há uma presença corporal, humana, em seu sentido mais físico e sentimental, no ato de contar histórias. Os contextos em que se deram as vivências relatadas são contrapostos àqueles do momento em que ocorre a narração, havendo, inevitavelmente, uma interferência de um sobre o outro.

Transcrevemos a seguir um último trecho de Benjamim (1994) que, acreditamos, descreve de modo bastante claro os pretos velhos:

Assim definido, o narrador figura entre os mestres e os sábios. Ele sabe dar conselhos: não para alguns casos, como o provérbio, mas para muitos casos, como o sábio. Pois pode recorrer ao acervo de toda uma vida (uma vida que não inclui apenas a própria experiência, mas em grande parte a experiência alheia. $\mathrm{O}$ narrador assimila à sua substância mais íntima aquilo que sabe por ouvir dizer). Seu dom é poder contar sua vida; sua dignidade é contá-la inteira. O narrador

\footnotetext{
13 A expressão "trabalhar no santo" indica que atualmente o Moçambique é uma entidade umbandista, um preto-velho no sentido religioso.

${ }^{14}$ Entrevista realizada em 15 de junho de 2017.
} 
é o homem que poderia deixar a luz tênue de sua narração consumir completamente a mecha de sua vida. [...]" (1994: 221).

No texto Benjamim menciona com certa nostalgia que essa figura do narrador estaria em vias de extinção, sobretudo pelo desvanecimento da capacidade de ouvir. Ousamos afirmar, contudo, que a arte de narrar permanece viva na cultura popular através das sementes lançadas pelas palavras andarilhas dos pretos velhos.

Sobre passados e antepassados comuns: uma família extensa

"Mãe", "mama", "mammy", "pai", "uncle" são alguns dos vocativos usualmente empregados para se referir a esses personagens de escravizados idosos da cultura popular. A aplicação dessas denominações de parentesco particulariza e aproxima uma ancestralidade vislumbrada como coletiva no contexto afro-americano. Tratamos como "avó" ou "pai” aquele senhor negro que não necessariamente possui laços sanguíneos conosco -embora comunguemos, muito provavelmente, um passado comum marcado pela escravidão. Trata-se, afinal, não da "minha" ou da "sua" avó, mas da "nossa" associando esse pronome possessivo no plural a uma enorme coletividade americana em cuja história ainda afloram as marcas do regime escravista.

Leslie Pollard (1981) ao estudar o sistema escravista norte-americano sob a ótica da velhice afirma que "mammy", "untie" e "uncle" seriam os termos normalmente empregados para se referir aos escravizados mais velhos, que já estivessem há muitos anos na mesma propriedade. $\mathrm{O}$ autor retoma Herbert Gutman e salienta que distintas razões levariam os senhores, de um lado, e os demais escravizados, de outro, a se referirem dessa maneira aos mais idosos. Para os primeiros seria uma forma de diferenciá-los dos demais escravizados, demonstrando maior respeito e, dentro de certos limites, um vínculo mais próximo. Já para a comunidade de escravizados, seria um meio de "investir 
relações não consanguíneas de significados simbólicos de parentesco" (1981: 229, tradução nossa). ${ }^{15}$

Especificamente acerca do emprego do vocativo "Pai", Martha Abreu retoma o Vocabulário Pernambucano de Pereira da Costa, organizado no século XIX, para demonstrar que este seria o "tratamento de respeito dado aos pretos velhos, e noutros tempos mesmo, indistintamente, a livres e escravos: Pai João, Pai Antônio, etc.” (COSTA apud ABREU, 2004: 268, grifo nosso). A autora ainda busca referências numa obra de 1910 de Alexina Magalhães Pinto em que há uma associação direta entre o termo "uncle"16 em inglês e o "pai" em português. Aparentemente essa aproximação entre essas duas denominações de parentesco seria conhecida no período, muito provavelmente daí a tradução de Uncle's Tom Cabin para A Cabana do Pai Tomás.

Não obstante as possíveis variações, percebe-se claramente que as designações familiares empregadas remetem, invariavelmente, a alguém mais idoso que o interlocutor. Explicando melhor: não importa a nossa idade, ao nos referirmos a um preto velho -seja ele o Pai João do folclore, a mama vieja montevideana, ou a Vovó Chica da umbanda ${ }^{17}$ - sempre nos colocamos numa posição de pessoas mais novas. Nós os designamos a partir de vocativos de parentesco associados a alguém -em perspectiva- mais velho que nós. Se o preto velho a quem nos referimos é o vô José ou a mãe Maria, nós nos

\footnotetext{
15 [...] invested non-kin slave relationships with symbolic kin meaning. 16 Tio.

${ }^{17}$ A umbanda é uma religião brasileira cujas origens remetem à cidade do Rio de Janeiro e ao início do século XX. Centrada em fenômenos de incorporação mediúnica, a umbanda sincretiza elementos religiosos do catolicismo, da pajelança indígena, do espiritismo kardecista e da macumba africana. Sua ritualística baseia-se em consultas oferecidas às pessoas que frequentam os templos por médiuns que se declaram incorporados por determinados espíritos. Estes são organizados em grupos específicos ou falanges, como os pretos-velhos (espíritos de antigos escravizados), caboclos (indígenas) e exus / pomba-giras (usualmente com ascendência europeia, associados à noite e à criminalidade, como assassinos, ladrões, prostitutas, dançarinas...). Durante essas consultas é possível tratar dos mais variados temas, como saúde, amor e emprego. Para mais informações ver: REZENDE (2017); BROWN (1994); MALANDRINO (2010); ORO (1999).
} 
colocamos no lugar de neto ou filho. Em se tratando de uma hierarquia familiar tradicional, essa estruturação já implica que lhe devemos respeito ${ }^{18}$.

Analisar essa noção de senilidade/familiaridade associadas às tradições familiares de uma matriz afro-americana talvez auxilie na compreensão de sua relevância. Dentre as várias entrevistas realizadas por Olaza (2009) com afrodescendentes no contexto uruguaio, diversos relatos evidenciam o valor dos ancestrais. Transcrevemos a seguir as falas de Julio e Danilo, respectivamente:

Minha avó falava muito pouco sobre os negros, muito poucas vezes, mas tinha um rico acervo cultural em matéria de contos. Tinha muita imaginação, então sempre me contava. Eu ia de férias com meu primo e era costume dela, de noite nos dava comida [...] e nos contava contos. E os contos eram todos mágicos, todos tinham a ver com espíritos, com aparecimentos, com o milagre daquele que se perde e é guiado por alguém sem saber o porquê, e isso me ensinou muito (2009: 35, tradução nossa ${ }^{19}$ ).

A nossa escola era minha avó (2009: 35, tradução nossa ${ }^{20}$ ).

A significação dos anciões está claramente atrelada à sua sabedoria e à sua capacidade de transmitir um conhecimento sobretudo pela oralidade, conforme trabalhamos no tópico anterior. Jorge Drexler, renomado cantor uruguaio, possui uma canção, Tamborero (tradução nossa), escrita em homenagem a outra figura muito famosa no cenário cultural e social do país, Fernando Lobo Nuñez, músico, luthier de instrumentos de percussão e bisneto de escravizados. Transcrevemos parte da letra a seguir:

O pai do pai do tamboreiro

Está contando a seu neto

A história daquele tambor

Como havia contado a seu pai seu avô

18 Pollard (1981) menciona o uso do termo "Old" (velho) precedendo o nome de um escravizado idoso mais respeitado na propriedade onde vivia, no contexto norte-americano, como por exemplo em "Old Tom".

${ }^{19}$ Mi abuela hablaba muy poco acerca de los negros, muy pocas veces, pero sí lo que tenía era un rico acervo cultural en materia de cuentos. Tenía mucha imaginación, entonces siempre me hablaba, yo iba en vacaciones com mi primo, y era costumbre de ella, de noche no daba de comer [...] y nos contaba cuentos. Y los cuentos eran todos mágicos, todos tenían que ver com espíritus, con aparecidos, con el milagro del que se pierde y alguién lo guia y no sabe por qué y que me enseño mucho.

${ }^{20}$ La escuela de nosotros era mi abuela. 
Que dizem, havia contado a ele seu irmão mais velho

A história que é longa e às vezes é triste

Resiste se transmitida entre gerações ${ }^{21}$

A associação que se estabelece entre senilidade e sabedoria vincula, inegavelmente, a existência desse antepassado à preservação das tradições e à transmissão do conhecimento. Halbwachs (2006) chegou a mencionar como a presença de um parente de idade avançada pode insuflar vitalidade ao que sabemos sobre o passado:

Muitas vezes é na medida em que a presença de um parente idoso está de alguma forma impressa em tudo o que este nos revelou sobre um período e uma sociedade antiga, que ela se destaca em nossa memória - não como uma aparência física um tanto apagada, mas com o relevo e a cor de um personagem que está no centro de todo, um quadro, que o resume e o condensa (2006: 85).

Nesse sentido, retomamos novamente o estudo de Halbwachs (2006) e seu argumento de que os contextos sociais serviriam de baliza às construções da memória. Tanto a afetividade quanto essa familiaridade remetem, ainda à noção de próximo trabalhada por Paul Ricoeur e retomada por Margarida Neves (2009). Esse próximo intermediaria as relações entre as memórias pessoais de um indivíduo e uma memória coletiva, transmutando "o coletivo abstrato e impessoal em experiência concreta e pessoal" (2009: 28).

No caso dos pretos-velhos umbandistas, essa proximidade pode ser percebida não somente pelo pronome de tratamento usualmente empregado, mas também pelo carinho e ternura a eles dedicados pelos consulentes. Conforme mencionado por Marina Rougeon: “eles [os pretos-velhos] despertam um sentimento de familiaridade e costumam aludir a um parentesco espiritual" (2017: 296, tradução nossa ${ }^{22}$ ). Nunes-Pereira (2006: 103) também trata do tema, mencionando que a construção desse ambiente familiar com as entidades cria uma relação pautada em sentimentos como a proteção, a identificação, o

\footnotetext{
${ }^{21}$ El padre del padre del tamborero / le esta contando a su nieto / la historia de aquel tambor / Como le contó a su padre su abuelo / que dicen le había contado a él, su hermano mayor / La historia que es larga y a veces es triste / resiste si se descarga en cada generación.

${ }^{22}$ La tendresse et l'émotion avec lesquelles les adepte leur portent une devotion [...] indiquent qu'ils suscitent un sentiment de familiarité et renvoient souvent à une parenté spiritualle.
} 
consolo e, sobretudo, o amor. Estabelece-se um laço de "suporte social" mútuo, em que tanto o preto-velho quanto o consulente se sentem "cuidados".

Nesse ponto é possível erigir ainda um paralelo com a própria noção de família extensa apresentada por Slenes (1999), baseada na concepção de ancestralidade bantu. Esta não estaria vinculada a um lugar físico, mas a uma "posição genealógica" (SLENES, 1999: 147). Não importaria quão longe eles estivessem de sua terra natal, seus ancestrais eram sempre levados consigo -a partir de distintas formas de representação- e devidamente cultuados. Conforme mencionado por Daibert (2015: 12), essa noção de ancestralidade estaria vinculada a figuras de extrema importância para os bantu, quase míticas, cujas histórias de vida seriam usualmente ignoradas dado o distanciamento espacial e temporal em que teriam vivido -o que não reduzia em nada sua relevância em termos sociais e religiosos.

Nunes-Pereira (2006: 83) usa uma frase proferida por um garotinho de nove anos como título de sua dissertação: "É meu avô, ora!”. O pesquisador relata que questionou o menino, que estava visitando o terreiro por ele pesquisado, sobre quem seria Pai Cipriano das Almas, entidade chefe do local. Segundo ele, a criança teria rebatido pronta e espontaneamente com a frase acima, como se a resposta fosse evidente. A despeito de o garoto ter usado o pronome possessivo no singular, entendemos que a frase talvez tenha mais correspondência com a realidade se utilizada na versão coletiva: em última instância os pretos velhos são os avós de todos nós.

\section{Uma delicada tessitura de crenças: o catolicismo afro-brasileiro}

Ressoam os atabaques na Choupana do Chico Baiano e Pai Elias em São João del-Rei, Minas Gerais. Os cânticos rituais são entoados, solicitando licença à espiritualidade (Deus, orixás e guias protetores do terreiro) para que tenham início os trabalhos. No momento em que os pontos cantados $^{23}$ ecoam

\footnotetext{
${ }^{23}$ Os pontos são entendidos no sentido literal como pontos de contato entre os mundos dos vivos e dos mortos. Seriam responsáveis por criar portais que permitem a comunicação entre essas realidades: através das canções que são entoadas para convocar as entidades, firmá-las em
} 
pelo salão os médiuns, cada qual de uma maneira muito particular, modificam sua postura e seus movimentos. Alguns se curvam imediatamente, como se o peso de muitos anos lhes tivesse sido depositado no dorso. Outros tremem incontrolavelmente braços, mãos ou pernas. Há ainda aqueles que se apoiam em bengalas enquanto caminham, mancando e com dificuldade, até os tocos de árvore ou banquinhos de madeira onde permanecerão durante longas horas. Eles passam, então a organizar os objetos com os quais irão trabalhar naquela noite. De um lado estão terços e rosários de contas de lágrimas ${ }^{24}$; imagens de Nossa Senhora do Rosário, São Benedito, São Jorge; estandartes com pinturas de Arcanjos e Santo Antônio; pequenos potes de vidro com "óleo santo" água benta; e vasilhas com "incenso de igreja". Compartilhando o mesmo espaço encontram-se galhos, sementes e folhas de ervas dos mais diversos tipos; guias $^{26}$ de proteção e firmeza; fitas amarradas nos punhos com as cores dos orixás de devoção dos médiuns; imagens desses mesmos orixás; cachimbos; fumos de rolo; pedras; velas de várias cores; toalhas brancas com bordados que remetem às entidades umbandistas; $p e m b a^{27}$; e bacia com água onde são preparados os banhos para os consulentes.

Esse breve vislumbre de uma gira $^{28}$ de pretos-velhos nos permite constatar um intrincado entrelaçamento de cosmologias, crenças e símbolos. A tentativa analítica de desatar os laços que tecem essa construção nos leva a

terra ou se despedir das mesmas (os chamados pontos cantados) ou através de signos que são grafados no chão (os pontos riscados).

${ }^{24} \mathrm{O}$ rosário normalmente usado pelos pretos-velhos é feito com as sementes de uma planta chamada lágrima de Nossa Senhora. Segundo Rougeon (2017), retomando estudo de Martins, há um mito que justificaria essa preferência. Diz-se que Maria teria aparecido a um grupo de escravizados e, compadecida por seu sofrimento, verteu lágrimas. Estas, ao tocarem o solo, germinaram na forma da planta. Como forma de agradecer e homenagear a virgem, eles passaram a confeccionar seus rosários com as sementes.

${ }^{25} \mathrm{O}$ óleo santo usado nos terreiros é adquirido nas igrejas católicas, sendo conhecido também como óleo ungido.

${ }^{26}$ As guias são colares feitos a partir de miçangas, sementes, cascas e outros objetos. Normalmente os umbandistas usam diversos deles, cada qual associado a um orixá ou entidade.

${ }^{27}$ A pemba é uma espécie de giz branco com que usualmente as entidades riscam seus pontos no chão. Segundo Sweet (2007: 174), a pemba na África Centro-Ocidental seria uma espécie de barro branco, associado a um mundo subterrâneo feito deste material, para onde se dirigiriam os mortos após seu falecimento. Posteriormente a pemba teria passado a ser associada com espíritos benevolentes.

${ }_{28}$ Gira é o termo normalmente empregado pelos umbandistas para se referir aos rituais que ocorrem nos terreiros. 
puxar fios das mais distintas matrizes religiosas. Não se pode negar a intensa influência do cristianismo, embora elementos de religiões africanas permeiem a elaboração das representações desse escravizado idoso.

Confluências, pacíficas ou não, entre o catolicismo e as crenças africanas foram extensamente trabalhadas por alguns autores, sobretudo John Thornton (2004) e Marina de Mello e Souza (2001, 2002a, 2002b). O primeiro autor debruçou-se, principalmente, sobre os processos de cristianização na África centro-ocidental, cunhando o termo cristianismo africano para referenciar o processo de aproximação entre os dois conjuntos de conhecimentos religiosos. Esse acercamento só foi possível em função da existência de um substrato relativamente semelhante entre as duas cosmovisões, especialmente no que diz respeito à crença na existência de um outro mundo não visível, acessível mediante o que ele chama de "revelações". Estas seriam, segundo o autor, uma espécie de janela entre os mundos, um canal que permitiria a troca de informações entre eles. Apesar de os meios e instrumentos através dos quais haveria essa comunicação diferirem entre as estruturas católicas e centro-africanas, fez-se possível uma tradução entre as duas visões, tornando-as, de certa forma, inteligíveis e aceitáveis para ambos os lados (obviamente não de maneira irrestrita).

Salientamos que o resultado desse diálogo sobrepõe, como a organização dos termos no conceito já demonstra, o "catolicismo" sobre o "africano". Em síntese, os adeptos dessa nova concepção religiosa internalizavam (deliberada ou impositivamente) um conjunto de verdades e dogmas cristãos, não sem antes passá-los pelo filtro de suas próprias tradições religiosas. Havia, ainda, a refutação de parte da doutrina católica, o que tornava esse catolicismo africano díspar do europeu. Thornton (2004: 343) salienta, ademais, que não ocorria a superposição absoluta de uma religião sobre a outra.

O autor não se aprofunda, contudo, no estudo do processo de construção desse catolicismo no Novo Mundo. Ele menciona somente de modo superficial que haveria especificidades no que se refere ao cristianismo africano nessa região. É justamente nessa lacuna que se inserem as pesquisas de Marina de 
Mello e Souza (2001, 2002a, 2002b). A autora cunha uma nova terminologia que melhor se adequa ao contexto e à nossa análise sobre os escravizados idosos, sobretudo os pretos-velhos umbandistas: catolicismo afro-brasileiro ou catolicismo negro no Brasil. Os dois elementos primordiais que influenciam no processo de construção deste catolicismo proposto por Souza seriam a reunião de várias cosmogonias africanas na realidade brasileira e imposição/opressão associadas à religião num contexto escravista. Na visão da autora o catolicismo afro-brasileiro seria vivenciado pelos escravizados a partir de uma reinterpretação de símbolos, ritos e dogmas, tendo como base suas culturas de origem. A aceitação da crença cristã passava inevitavelmente por essa ressignificação de suas próprias crenças.

Um bom exemplo dessa confluência de aportes também pode ser encontrado no personagem Pai Benedito de José de Alencar. Nas palavras do autor:

É natural que já não exista a cabana do pai Benedito. Há seis anos ainda eu a vi, de onde saía o preto velho. [...] Curioso de ver de perto o tronco do ipê descobri junto às raízes pequenas cruzes toscas, enegrecidas pelo tempo ou pelo fogo. Do lado da nascente, havia uma imagem de Nossa Senhora em barro, um registro de São Benedito, figas de pau, feitiços de várias espécies, cascavéis e dentes de cobras (2009: 7-8).

O feitiço africano, com sua manipulação de elementos naturais caminha paralelamente e em harmonia com a devoção católica. Há, ainda, uma comunhão de valores. Os pretos velhos são popularmente conhecidos por praticarem o bem, dando suporte físico e psicológico àqueles que os buscam. Um dos exemplos mais ilustrativos dessa "função" talvez tenha sido proporcionado pela escola de samba carioca Paraíso do Tuiuti em 2018.

A comissão de frente denominada "O grito da liberdade" representava escravizados sendo brutalmente açoitados. Um deles surge, em determinado momento, agonizante. Ele passa a receber os cuidados de um grupo de pretos velhos que emerge de uma senzala. Trajando calças brancas, camisas xadrez em branco e preto e chapéu de palha, eles carregam um lenço xadrez na mesma tonalidade que se transforma repentinamente em bengala, além do clássico 
terço de contas de lágrima. Caminhando encurvados e com dificuldade, eles benzem o escravo ferido com sinais da cruz e a fumaça do cachimbo, curando-o e, de certa forma, transferindo a força e a sabedoria que detêm. Ele arrebenta, então, suas correntes enquanto o capataz dá mostras de arrependimento.

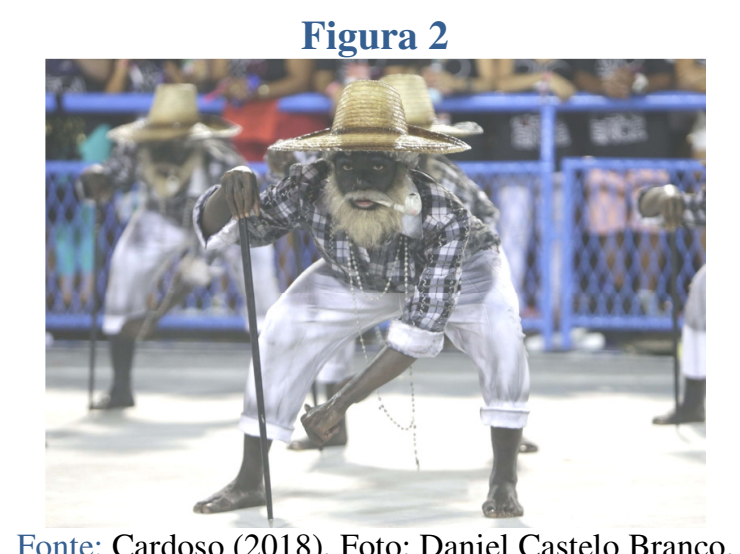

Em entrevista ao jornal O Globo (AZEVEDO, 2018) o coreógrafo Patrick Carvalho, responsável pela ala, explicou o papel dos pretos-velhos na avenida:

$\mathrm{O}$ velho sábio te liberta de muita coisa. Lembro que a minha bisavó tinha um remédio certo para qualquer machucado. Quando os personagens saíam da senzala, eles purificavam aquele lugar cheio de dor, de pressão, de sofrimento. E quando eles voltavam para a senzala, e os negros saíam, não saíam libertos, ainda saíam presos, mas com a força da liberdade.

Cabe ressaltar como essa sabedoria que agrega elementos dos mais diversos cultos é percebida, aceita e, de certa forma, aplicada pela sociedade. Conforme mencionado por Zilvan Lima, consulente e seguidor das religiões afro-brasileiras (REZENDE, 2017):

Quando eu imagino os negros escravizados, vindos da África ou então já nascidos aqui no Brasil e se deparando com isso [a religião católica], como ele vê, e o quanto foi importante estabelecer um diálogo, ter uma relação com esses símbolos, pra sobreviver. [...] Quer dizer que o cara foi forte o bastante pra manter a fé dele ali nos ancestrais dele, se apropriando de coisas de outra religião. [...] O negro-velho pra mim tem a ver com essa energia que acolhe, que acolhe e por isso transforma. 
Os diálogos religiosos, para além de auxiliarem nas vivências do cotidiano dos escravizados, são percebidos como uma forma de força e de resistência. A confluência de aportes oriundos do catolicismo e das crenças africanas permitiria um consolo e sustentáculo em termos de fé, ao mesmo tempo em que ofereceria uma espécie de "camuflagem" à manutenção de crenças prévias.

\section{O escravizado idoso no emaranhado dos tempos}

Percebemos a partir das problematizações acima que a construção desses personagens de escravizados idosos se sustenta em alguns aspectos primordiais e bastante semelhantes, a despeito das especificidades de cada um deles. As permanências apresentadas na elaboração das representações nos permitem inquirir a partir de determinados aportes teóricos os sentidos dessa perenidade no tempo e no espaço, uma vez que as correspondências se dão nos mais diversos momentos, países e ambientes.

"O que significa a divinização de escravos nos ritos contemporâneos em que se cultuam os pretos-velhos?" (SOUZA, 2006: 6). Apoiada por essa indagação, calcada na seara religiosa e no presente, Mônica Souza desenvolve longa pesquisa em que analisa a etnografia dos rituais e as representações de seus participantes em diversas religiões ${ }^{29}$ - sendo a coincidência essencial entre elas o culto aos pretos-velhos. A autora parte dessa noção de sacralização da figura do escravizado culminando em uma análise da própria construção social da identidade brasileira. Em suas palavras, "os pretos-velhos são seres sobrenaturais dotados de uma "força" pelo fato de terem sido escravizados" (SOUZA, 2006: 124). Embora concordemos em termos com a pesquisadora, entendemos que há um elemento relevante que foi ignorado na pesquisa. $\mathrm{Na}$ nossa concepção não há a divinização do escravizado, mas, sim, do escravizado idoso. O status de sagrado é, na prática, reservado ao velho. A velhice é

\footnotetext{
29 A autora empreende a pesquisa com: umbanda, candomblé, barquinha, um grupo mais próximo ao kardecismo e um grupo de estudos espiritualistas.
} 
claramente evidenciada nas representações dos pretos-velhos, seja na postura dos médiuns (que a despeito de referenciar o sofrimento, também remete à senilidade) ou nas imagens que povoam os altares umbandistas (os cabelos e barbas brancas, além das rugas, são elemento constante). A dimensão temporal é crucial para a construção dessa entidade divinizada.

A despeito do ineditismo e da relevância acadêmica e social dos trabalhos de Mônica Souza (2006), nos propomos a dar um passo além, demonstrando de que forma a afirmada sacralidade dos pretos-velhos ultrapassaria os limites dos terreiros e templos religiosos afro-americanos, imiscuindo-se, já há algum tempo, em outras searas da cultura afro-latinoamericana. Sob nossa ótica, ocorre com os escravizados idosos um fenômeno discutido de maneira superficial (em decorrência de sua morte) por Mircea Eliade (2010): a camuflagem do "sagrado" em roupagem aparentemente "profana", sem, contudo, despi-lo de suas vestes sacras. Trata-se de uma acepção muito próxima à noção de sagrado selvagem apresentada por Roger Bastide (2006). Seria, conforme defendido por este, a representação de um sagrado não domesticado nas entranhas de uma religião formal, um sagrado "difuso" que embora julgue inventar novas entidades ressuscita aquelas que estavam adormecidas em outros contextos (BASTIDE, 2006: 273).

Baseando-se nessa problematização e considerando os personagens anteriormente tratados, como os folclóricos Pai João e Mãe Maria, o Pai Tomás da literatura, a mama vieja uruguaia ou as entidades dos terreiros umbandistas, constatamos que todas essas representações de escravizados idosos poderiam ilustrar o conceito de hierofanias nos termos de Eliade (2016), entendidas como manifestações de algo sagrado, independentemente de sua presença em espaços formalmente religiosos. Nos casos em que hierofanias possuam sentido e são legitimadas por grupos cada vez maiores, elas se tornam multivalentes e universalistas. No caso específico dos escravizados idosos percebemos que seus significados lograram transbordar as fronteiras políticas dos países e adquiriram uma sacralidade em níveis continentais. 
Essa perspectiva mais ampliada acerca dos escravizados idosos nos instigou a retomar as teorias sobre memória para uma melhor compreensão desses personagens. Myrian Sepúlveda Santos menciona que:

[...] a memória tanto está presente em nós, quanto é, também, exterior a nós. Há objetos que guardam a memória e nos fazem lembrar das mais diversas maneiras. [...] Construções coletivas do presente também guardam memórias de experiências passadas. Também nesses casos, a memória que temos do passado não é una e indivisível. A memória se cristaliza fora de nós, em lendas, monumentos e objetos que estão longe de ser reflexos de verdades históricas (SANTOS, 2003: 274, grifo nosso).

Essa passagem oferece alguns indícios acerca das possibilidades de apreciação de que dispomos. É possível que elementos e situações que nos são externos condensem determinadas memórias. No nosso entendimento, esse processo de "cristalização" não implica em imutabilidade eterna; embora dificilmente aceite modificações muito bruscas ou repentinas. Haveria uma maior estabilidade no regime de construção e ressignificação dessas memórias, o que provocaria uma lentidão muito maior em eventuais transformações.

Seguindo essa mesma linha de raciocínio, encontramos o conceito de monumentalização proposta por Aleida Assmann (2011). Para formular dita concepção - à qual retornaremos em breve -, a pesquisadora desenvolveu, em conjunto com Jan Assmann, o conceito de memória cultural (ASSMANN, 2011; ASSMANN, 2016). Este seria resultado de uma decomposição da memória coletiva de Halbwachs (2006) em duas: memória cultural e memória comunicativa. A última diria respeito às memórias que um indivíduo compartilha com seus contemporâneos e estaria mais próxima à noção de Halbwachs, além de consistir no objeto primordial de estudo da história oral. Conforme dito por Jan Assmann:

A memória comunicativa não é institucional; não é mantida por nenhuma instituição que vise ensinar, transmitir ou interpretar; não é cultivada por especialistas e não é convocada ou celebrada em ocasiões especiais; não é formalizada ou estabilizada por nenhuma forma de simbolização material; ela vive na interação e na comunicação cotidiana e, por essa única razão, tem uma profundidade de tempo limitada, que normalmente alcança 
retrospectivamente não mais que 80 anos, o período de três gerações que interagem (ASSMANN, 2016: 119).

Já a memória cultural é uma espécie de instituição. Retomando novamente Assmann:

Ela é exteriorizada, objetivada e armazenada em formas simbólicas que, diferentemente dos sons de palavras ou da visão de gestos, são estáveis e transcendentes à situação: elas podem ser transferidas de uma situação a outra e transmitidas de uma geração a outra (ASSMANN, 2016: 118).

A definição de memória cultural ainda contempla o entendimento de que há "símbolos externos" (monumentos, imagens, objetos, ritos, textos, etc.) que embora não sejam dotados de uma memória própria estão carregados de memórias que foram a eles conferidos por uma pessoa ou um grupo. Esses símbolos atuam como gatilhos, estímulos a outras memórias. Em se tratando de coletividades eles são de certa maneira institucionalizadas com o intuito de serem recorporificados e, em determinado nível, preservados. Essa função estabilizadora da memória cultural poderia estar relacionada, além disso, às noções de segredo, esoterismo ou restrição da sabedoria a determinados grupos ou indivíduos. Há um "elitismo", nas palavras de Assmann (2016), na administração desse saber. O autor, estudioso das religiões, exemplifica essa gestão através do papel desempenhado pelos griots $^{30}$ africanos, xamãs, mulás, rabinos e sacerdotes. Todos eles cumpririam a função de "guardiões" de memória cultural. Extrapolando as fronteiras religiosas, Jan Assmann ainda aponta os trovadores, professores e artistas nesse grupo.

É fundamental e significativo pensar a memória cultural aplicada aos escravizados idosos na cultura popular. Eles são investidos, pelos mais variados meios - que vão desde a ritualística umbandista aos impactos íntimos e sociais da literatura e das manifestações de música e dança -, de uma capacidade de transmissão das memórias da escravidão, que independentemente de guardar ou não semelhanças com uma possível verdade histórica, são cotidianamente construídas, interpretadas, legitimadas e, de certa maneira, preservadas no ambiente cultural.

\footnotetext{
${ }^{30}$ Ver Hampaté Bâ (2010).
} 
A noção de "recorporificação" dessas memórias se assenta perfeitamente, por exemplo, ao rito em que os médiuns declaram incorporar os pretos-velhos. Nesse instante, essas pessoas, com seus respectivos objetos rituais, configuram-se enquanto símbolos de uma memória do cativeiro tendo como base todos os elementos que a ela foram atribuídos. Usam-se roupas brancas de tecidos mais simples, chapéu de palha no caso dos homens e lenço ou turbante no caso das mulheres, bengalas feitas com pedaços de galhos, cachimbo e pés descalços em termos de vestimenta e artefatos. Ervas variadas são separadas para benzeções, banhos e chás, bem como velas, água de mina, de rios ou de mar. Feijoada, café, broas de milho e cocadas são ofertadas de forma ritualística. Os médiuns nesses rituais em que se declaram incorporados ainda adquirem novas tonalidades de fala, mais rouca, e fazem uso de vocabulário e gramática próprios - remetendo à maneira de falar de um estrangeiro recém chegado ao país e a dialetos africanos. Em termos de postura eles se curvam como se o peso de muitos anos lhes fosse depositado nas costas. Tremem mãos ou pés, caminham com dificuldade, usualmente necessitando do auxílio de outra pessoa ou do próprio cajado. Sentam-se em tocos de árvore ou bancos de madeira mais baixos. Seus gestos costumam ser lentos e a fala compassada e amorosa, como se fosse um avô ou avó tratando com um neto(a). Há ainda a questão dos nomes, posto que essas entidades recebem usualmente uma alcunha que congrega determinado grau de parentesco (conforme analisado anteriormente, pode variar entre pai, mãe, vó, vô, tia, dentre outros), um prenome com forte conotação cristã (Maria, João, Francisco, José...) e um indicativo de lugar que usualmente remete à África ou a fazendas do período escravista (do Congo, Moçambique, de Aruanda, do Engenho...). ${ }^{31}$

Cabe ressaltar que a despeito das especificidades de cada terreiro, de cada localidade, e de cada entidade, salta aos olhos a similitude entre os pretosvelhos das cidades que pesquisamos com os de outros locais que eventualmente

\footnotetext{
${ }^{31}$ Para mais informações sobre a postura, objetos e nomes rituais ver REZENDE (2017). A respeito da construção linguística ver ALKMIN; LOPÉZ (2015).
} 
visitamos e com aqueles descritos em outras pesquisas ${ }^{32}$. As formas de incorporação e as representações imagéticas são bastante semelhantes. Há, inegavelmente, um substrato cultural comum e compartilhado que nos permite analisar os pretos-velhos à luz do conceito de memória cultural. Essa percepção torna-se ainda mais interessante ao observarmos que a maioria dessas características transbordam as fronteiras das religiões formais, podendo ser encontradas nos outros personagens de que tratamos anteriormente. Apresentamos a seguir algumas imagens para ilustrar essa aproximação. A figura 3 consiste na capa do livro $O$ tronco de ipê de José de Alencar, com a figura de Pai Benedito; a figura 4 traz a capa de A cabana de Pai Tomás, com destaque para o personagem principal, de Harriet Beecher Stowe; por fim, a figura 5 ilustra um preto-velho umbandista.

Figuras 3, 4 e 5

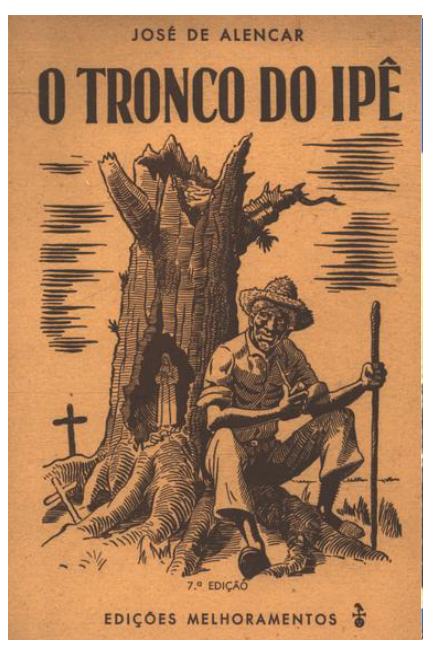

Fonte: ALENCAR (1957)

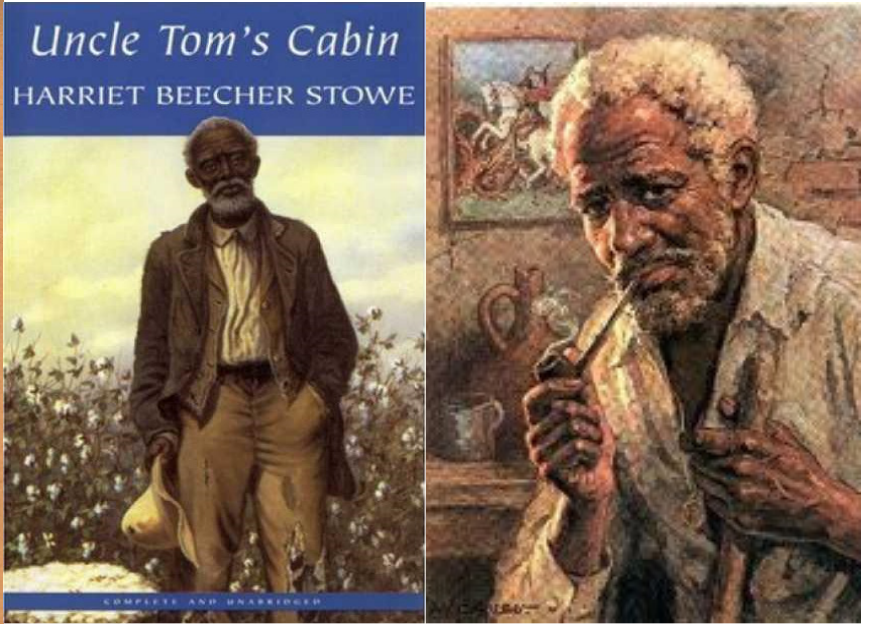

Fonte: LOYAL (2019)

Fonte: RAÍZES (2019)

Retomemos, então, o conceito de monumentalização de Aleida Assmann:

A monumentalização da história são os dramas, à medida que fazem desfilar personagens e cenas inesquecíveis diante dos olhos. Inesquecível é o que está afetivamente carregado. Monumentalização significa a densificação e intensificação

\footnotetext{
${ }^{32}$ SOUZA (2006), DIAS (2011), HALE (1997), NUNES-PEREIRA (2006), SANTOS (1999), ALKMIN; LOPÉZ (2015).
} 
estética de acontecimentos em figuras eficazes para a recordação. Estudiosos da literatura tendem a associar estetização com aumento de vagueza e distância; aqui, no entanto, estetização significa sensualização de conhecimento histórico abstrato. A atribuição de forma estética está a serviço de uma formação concisa simpática à memória e conformadora da memória. História, poesia e memória celebram com isso uma estreita união entre si (ASSMANN, 2011: 88-89, grifo nosso).

É quase inconcebível separar essa dimensão afetiva e estética (no sentido acima proposto) da figura dos escravizados idosos. A construção cultural, folclórica, literária e religiosa de um preto velho é historicamente didática exatamente porque oferece a essa memória áspera, dura, de um "passado sensível" 33 para praticamente a totalidade da população americana, uma roupagem mais leve, "acessível”, mais próxima e, por que não, familiar. Conforme almejamos demonstrar ao longo deste artigo, os elementos que aproximam os diversos escravizados idosos que mencionamos aqui (passando pela arte de narrar, pelos vocativos de parentesco e mesmo pela religiosidade) implicam numa construção memorialística afetiva, fascinante, encantadora e envolvente. Ouvir as anedotas de Pai João com sua maneira característica de se expressar e agir, perscrutar as falas do Pai Benedito de José de Alencar (2009), acompanhar uma mama vieja no desfile de llamadas em Montevidéu, reler a saga de Pai Tomás de Harriet Beecher Stowe (1966), ou se consultar com um preto-velho umbandista viabiliza muito mais que a mera "recorporificação" da figura do escravizado. O contato íntimo com esses personagens conforma cotidianamente uma memória popular do cativeiro.

A atribuição a esses personagens de um status de monumento não implica na garantia de veracidade histórica daquilo que representam ou narram. Refere-se, obviamente, a um processo de construção memorial a partir de parâmetros do presente. Conforme apontado por Myrian Santos: "não se trata de investigar o passado através da memória, mas de procurar compreender o presente a partir das reconstruções que são feitas do passado" (SANTOS, 2003:

\footnotetext{
${ }^{33} \mathrm{Na}$ terminologia empregada por Hebe Mattos no prefácio de COOPER; HOLT; SCOTT, 2004 e em MATTOS, 2001.
} 
275). Não obstante certa "institucionalização" dessa memória, ela é alvo diário dos mais distintos inputs, que podem variar com os contextos sociais, políticos, culturais, etc.

Um exemplo interessante de uma possível mudança na forma como essas memórias do cativeiro associadas aos escravizados idosos são elaboradas nos é oferecida por uma comparação entre os enredos da escola de samba carioca Paraíso do Tuiuti, em 2018, e da Estação Primeira de Mangueira, de $1964^{34}$. Transcrevemos, primeiramente, a letra do samba desta última, denominado Histórias de um preto velho:

Era uma vez um preto velho
Que foi escravo
Retornando a senzala
Para historiar o seu passado
Chegando a velha Bahia
Já no cativeiro existia
Preto velho foi vendido
Menino a um senhor
Que amenizou a sua grande dor
Quando no céu a lua prateava
Que fascinação
Preto velho na senzala
Entoava uma canção
Ôôô̂ô
Conseguiu tornar realidade
O seu ideal a liberdade
Vindo para o Rio de Janeiro
Onde o progresso despontava
Altaneiro
Foi personagem ocular
Da fidalguia singular
Terminando a história
Cansado da memória
Preto velho adormeceu
Mas o lamento de outrora
Que vamos cantar agora
Jamais esqueceu

(SAMBA, 2018, grifo nosso)

Edifica-se aqui uma imagem de preto velho passivo, cuja liberdade foi, aparentemente, concedida por um senhor. Embora não tenha se olvidado dos lamentos de outrora, o personagem adormece, fatigado pela memória. $\mathrm{Na}$

\footnotetext{
${ }^{34} \mathrm{Na}$ ocasião a escola ficou em terceiro lugar.
} 
canção ele adota uma postura muito mais de testemunha, de espectador dos acontecimentos, que de proatividade. Outro elemento que merece atenção é a expressão que dá início ao samba: "era uma vez", remetendo aos contos de fadas e fábulas, histórias fantasiosas, mágicas e supostamente distantes no tempo e no espaço. Esse marcador estabelece uma dissonância entre dois planos de enunciação: aquele que conta e aquele sobre o qual se conta. Há, de certa forma, a fixação de uma fronteira para esse acontecimento no tempo passado, sendo a lembrança dessa história seu único vínculo com o presente.

Retomemos agora o samba-enredo da Paraíso do Tuiuti, de 2018.

Irmão de olho claro ou da Guiné

Qual será o valor? Pobre artigo de mercado

Senhor eu não tenho a sua fé, e nem tenho a sua cor

Tenho sangue avermelhado

O mesmo que escorre da ferida

Mostra que a vida se lamenta por nós dois

Mas falta em seu peito um coração

Ao me dar escravidão e um prato de feijão com arroz

Eu fui mandinga, cambinda, haussá

Fui um rei egbá preso na corrente

Sofri nos braços de um capataz

Morri nos canaviais onde se planta gente

$\hat{\mathrm{E}}$ calunga! $\hat{E}$ ê calunga ${ }^{35}$ !

Preto Velho me contou, Preto Velho me contou

Onde mora a senhora liberdade

Não tem ferro, nem feitor

Amparo do rosário ao negro Benedito

Um grito feito pele de tambor

Deu no noticiário, com lágrimas escrito

Um rito, uma luta, um homem de cor

E assim, quando a lei foi assinada

Uma lua atordoada assistiu fogos no céu

Áurea feito o ouro da bandeira

Fui rezar na cachoeira contra bondade cruel

Meu Deus! Meu Deus!

Se eu chorar não leve a mal

Pela luz do candeeiro

Liberte o cativeiro social

Não sou escravo de nenhum senhor

\footnotetext{
${ }^{35}$ Calunga é um termo de origem bantu muito usado nos terreiros de religiões afro-brasileiras para se referir ao ambiente de passagem entre o mundo dos vivos e dos mortos. Na umbanda usa-se calunga grande para fazer referência ao mar e calunga pequena para cemitério.
} 
Meu Paraíso é meu bastião
Meu Tuiuti o quilombo da favela
É sentinela da libertação

Percebe-se que o preto-velho aqui é o responsável por noticiar detalhes da liberdade, já vivenciada por ele no mundo dos espíritos. Sua voz e seu rosário servem de amparo para uma luta que continua não mais no âmbito jurídico ou legal, mas social. Há uma clara aproximação afetiva entre quem narra a história e o preto-velho: foi ele quem "me contou”. Embora não tenha conquistado o campeonato oficial, a escola foi a grande vencedora do Tamborim de Ouro, prêmio concedido pelo jornal O Dia; enquanto a comissão de frente conquistou o Estandarte de Ouro do Globo ${ }^{36}$. Se o samba-enredo da Mangueira foi nominado a partir de uma afirmativa (História de um pretovelho), a própria interrogação da Paraíso do Tuiuti (Meu Deus, meu Deus, está extinta a escravidão?) já denota uma mudança de percepção e de interpretação do passado.

Conforme mencionado anteriormente, a comissão de frente chamada de "O grito da liberdade" almejou representar a potência libertária do preto velho ao benzer e purificar o ambiente de dor e sofrimento das senzalas, dando o estímulo e a força necessários para que os escravizados se libertassem. O preto velho passa a exercer função primordial na própria concepção de libertação do cativeiro, ainda que mantenha suas características essenciais de narrador (preto velho me contou...), de sábio/feiticeiro e de ancestral (o bailarino, Vitor Feitosa, que interpretou o escravo abençoado pelos pretos-velhos declarou estar "muito honrado em representar toda a minha ancestralidade" ${ }^{37}$ ).

\footnotetext{
${ }^{36}$ Ambos os prêmios concedidos com o auxílio de votação popular.

${ }^{37}$ AZEVEDO, 2018.
} 
Figura 6

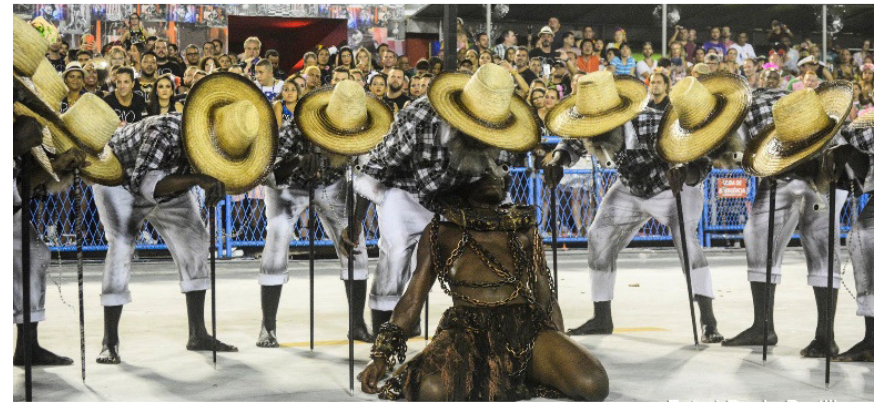

Fonte: ESCOLA, 2018. Foto: Paulo Portilho.

A base memorialística desse samba e a relevância social e política do preto velho hoje pode ser interpretada e percebida, mais que nunca, através de um novo entrelaçamento de temporalidades. Paralelamente à força impingida ao escravizado pelos pretos velhos que permitem sua libertação, temos a sugestão de que a escravidão, embora legalmente extinta, ainda teria reminiscências no presente, com, por exemplo, os quilombos das favelas e o cativeiro social mencionados na letra. Isso posto, amplifica-se a potência desses pretos velhos contemporaneamente.

Esse emaranhado de tempos aflora também nas falas de dois entrevistados uruguaios, que sempre saem juntos nas llamadas como mama vieja e gramillero: Charo Martinez, afro-uruguaia, compositora de candombe e mama vieja e Julián Cabrera, bailarino, médium e responsável por um terreiro de umbanda, e gramillero. Nas palavras de Julián há um entrelaçamento muito profundo entre representar esse "herbalista" e incorporar um preto-velho, já que ambos implicariam num reencontro com sua ancestralidade. Seria uma forma de "entrar nesse mundo mágico da temporalidade. Há [num sentido de materialidade] quatrocentos anos naquele mesmo momento". Charo afirma categoricamente que dança para esses ancestrais, como uma forma de celebração e agradecimento por tudo aquilo que eles teriam feito (ela usa o termo "rebelião"), e que teria permitido a existência do candombe atualmente:

Porque o que eles [ancestrais] fizeram e o que eu posso fazer, meu filho vai desfrutar. E deixar a ele como legado o candombe - seu pai também é candombeiro. [...] Deixamos esse legado a Facu [Facundo, nome do seu filho], que vai além da casa, do dinheiro, dos títulos. Facu um dia vai se 
encontrar nisso. Ele tem dezessete anos. Eu o tenho que ensinar, contar a história a ele. Para que ele possa seguir escrevendo, do seu próprio lugar, algo mais para essa história, sabendo de onde ele vem. ${ }^{38}$

Tendo como base toda a discussão realizada até o momento, percebemos como a presença dos escravizados idosos em distintos lugares demonstra que sua construção no presente, ainda que calcada numa visão de passado, traz alento, ânimo, coragem e amparo, agindo diretamente sobre um horizonte de expectativas e sonhos quanto ao futuro. Encerramos o artigo com outra fala de Charo Martinez, que julgamos resumir bem os sentimentos que esses escravizados idosos provocam em muitas pessoas, além de demonstrar esse entrelaçamento de temporalidades consubstanciado por eles:

"Eu acredito que os ancestrais nos bendizem todo o tempo. E nos cuidam. E te mostram o caminho. Só é preciso estar atento aos sinais". ${ }^{39}$

\section{Referências}

ABREU, M. Da senzala ao palco: canções escravas e racismo nas Américas, 1870-1930. Campinas: UNICAMP, 2017.

ABREU, M. Outras histórias de Pai João: conflitos raciais, protesto escravo e irreverência sexual na poesia popular, 1880-1950. Afro-Ásia, Salvador, n. 31, p. 235-276, 2004.

ALENCAR, J. de. O tronco de Ipê. São Paulo: Melhoramentos, 1957.

ALENCAR, J. de. O tronco de Ipê. São Paulo: Rideel, 2009.

ALKMIN, T.; LÓPEZ, L. Registros da escravidão: as falas de pretos-velhos e de Pai João. Stockholm Review of Latin American Studies, Estocolmo, n. 4, p. 37-48, 2009.

ASSMANN, A. Espaços de recordação: formas e transformações da memória cultural. Campinas: UNICAMP, 2011.

\footnotetext{
${ }^{38}$ Porque lo que ellos hicieron y lo que yo puedo hacer, lo va a disfrutar mi hijo. Y dejarle como legado el candombe, su papá también es condombero. [...] le dejamos este legado a Facu, que va más allá de la casa, de la plata, de los títulos, Facu um día se va a encontrar em eso. El tiene 17. Yo le tengo que enseñar, como... contarle la historia. Para que el pueda seguir escribiendo. Desde su lugar, algo más para esta história, saber de donde viene.

${ }^{39}$ Yo creo que los ancestros nos bendizen todo el tempo. Y nos cuidan. Y te muestran el caminho. Hay que estar atento a las seãnles.
} 
ASSMANN, J. Memória comunicativa e memória cultural. Revista História Oral, Rio de Janeiro, v. 19, n. 1, p. 115-127, 2016.

ASSUNÇÃO, M. R. A memória do tempo de cativeiro no Maranhão. Revista Tempo, Niterói, v. 15, n. 29, p. 67-110, 2011.

AULA magna com Mia Couto. UFRGS TV, 2014. YouTube, publicado em 3 set. 2014.

AZEVEDO, E. 'Queria chamar Avenida para gritar comigo' diz coreógrafo da comissão de frente da Paraíso do Tuiuti. $O$ Globo, Rio de Janeiro, 12 fev. 2018 .

BASTIDE, R. Estudos afro-brasileiros. São Paulo: Perspectiva, 1983.

BASTIDE, R. O sagrado selvagem e outros ensaios. São Paulo: Companhia das Letras, 2006.

BENJAMIN, W. Magia e técnica, arte e política: ensaios sobre literatura e história da cultura. São Paulo: Brasiliense, 1994.

BROWN, D. DeG. Umbanda: religion and politics in urban Brazil. Nova Iorque: Columbia University, 1994.

CARDOSO, M. Paraíso do Tuiuti é a grande vencedora do Tamborim de Ouro de 2018. O Dia, Rio de Janeiro, 13 fev. 2018.

CASCUDO, L. da C. Literatura oral no Brasil. Brasília/São Paulo: Itatiaia/EDUSP, 1984.

DAIBERT, R. A religião dos bantos: novas leituras sobre o calundu no Brasil colonial. Estudos Históricos, Rio de Janeiro, v. 28, n. 55, p. 7-25, 2015.

DIAS, R. de N. Correntes ancestrais: os pretos-velhos do Rosário. 2011. Dissertação (Mestrado em Filosofia) - Universidade de São Paulo, Ribeirão Preto, 2011.

ELIADE, M. História das crenças e das ideias religiosas. Rio de Janeiro: Zahar, 2010.

ELIADE, M. Tratado de história das religiões. São Paulo: WMF Martins Fontes Ltda, 2016.

ESCOLA de Samba Paraíso do Tuiuti pergunta se a escravidão acabou no Brasil e brilha no Carnaval 2018 do Rio de Janeiro. Jornal Grande Bahia: Salvador, 14 fev. 2018.

EVARISTO, C. Becos da memória. Rio de Janeiro: Pallas, 2017. 
HALBWACHS, M. A memória coletiva. São Paulo: Centauro, 2006.

HALE, L. L. Preto velho: resistence, redemption and engendered representations of slavery in a Brazilian possession-trance religion. American Ethnologist, Nova Iorque, v. 24, n. 2, p. 392-414, mai. 1997.

HAMPATÉ BÂ. A tradição viva in KI-ZERBO (Ed.), História Geral da África, 2010, v. I, p. 167-212. Disponível em: https://unesdoc.unesco.org/ark:/48223/pf0000190249. Acesso em 25 jan. 20120.

LOYAL Books - Free Public Domain Audiobooks \& eBook Downloads. 2019. Disponível em: <http://www.loyalbooks.com/book/uncle-toms-cabin-byharriet-beecher-stowe>. Acesso em 21 jan. 2019.

MALANDRINO, B. C. "Há sempre confiança de se estar ligado a alguém": dimensões utópicas das expressões da religiosidade bantú no Brasil. 2010. Tese (Doutorado em Ciências da Religião) - Pontifícia Universidade Católica de São Paulo, São Paulo, 2010.

NEVES, M. de S. Nos compassos do tempo. In: SOIHET, R.; AZEVEDO, C. da S.; AlmeidA, M. R. C. de; GONTIJO, R. (Org.). Mitos, Projetos e Práticas Políticas: Memória e Historiografia. Rio de Janeiro: Civilização Brasileira, 2009.

NUNES-PEREIRA, S. H. É meu avô, ora! Um estudo sobre pretos-velhos no imaginário social brasileiro. 2006. Dissertação (Mestrado) - Pontifícia Universidade Católica do Rio de Janeiro, Rio de Janeiro, 2006.

OLAZA, M. Ayer e hoy: afrouruguayos y tradición oral. Montevidéu: Trilce, 2009.

ORO, A. P. Axé Mercosul: as religiões afro-brasilerias nos países do Prata. Vozes: Petrópolis, 1999.

POLLARD, Leslie. Aging and Slavery: A Gerontological Perspective. The Journal of Negro History, Chicago, v. 66, n. 3, p. 228-234, 1981.

RAÍZES espirituais. Disponível em: $<$ https://www.raizesespirituais.com.br/participe-das-comemoracoes-do-dia-dospretos-velhos/>. Acesso em 21 jan. 2019.

RAMOS, A. O folclore negro no Brasil: demopsicologia e psicanálise. Rio de Janeiro: Casa do Estudante do Brasil, 1935.

REIS, J. J.; SILVA, E. Negociação e conflito: a resistência negra no Brasil escravista. São Paulo: Companhia das Letras, 1989. 
REZENDE, L. L. Força africana, força divina: a memória da escravidão recriada na figura umbandista dos pretos-velhos. 2017. Dissertação (Mestrado em História) - Universidade Federal de São João del-Rei, São João del-Rei, 2017.

RIOS, A. L.; MATTOS, H. Memórias do cativeiro: família, trabalho e cidadania no pós-abolição. Rio de Janeiro: Civilização Brasileira, 2005.

ROUGEON, M. Les pretos-velhos dans l'umbanda: un culte brésilien aux ancêtres et aux esprits d'esclaves. Anthropologie et Sociétés, Québec, v. 41, n. 1, p. 281-315, 2017.

SANTOS, E. C. M. Preto velho: as várias faces de um personagem religioso. 1999. Dissertação (Mestrado em Antropologia Social) - Universidade Estadual de Campinas, Campinas, 1999.

SANTOS, M. S. dos. História e memória: o caso do Ferrugem. Revista Brasileira de História, São Paulo, v. 23, n. 46, p. 271-295, 2003.

SLENES, R. Na senzala uma flor: esperanças e recordações na formação da família escrava -Brasil Sudeste, século XIX. Rio de Janeiro: Nova Fronteira, 1999.

SOUZA, M. de M. e. Catolicismo negro no Brasil: santos e minkisi, uma reflexão sobre miscigenação cultural. Revista Afro-Ásia, Salvador, n. 28, p. 125-146, 2002a.

SOUZA, M. de M. e. Reis negros no Brasil escravista: história da festa de coroação de rei Congo. Belo Horizonte: Editora UFMG, 2002 b.

SOUZA, M. de M. Santo Antônio de nó de pinho e o catolicismo afrobrasileiro. Tempo, Niterói, v. 6, n. 11, p. 171-188, 2001.

SOUZA, M. D. de. Pretos-velhos: oráculos, crença e magia entre os cariocas. 2006. Tese (Doutorado em Antropologia) - Universidade Federal do Rio de Janeiro, Rio de Janeiro, 2006.

STOWE, H. B. A cabana do Pai Tomás. Rio de Janeiro: Bruguera, 1966.

SWEET, J. H. Recriar África: cultura, parentesco e religião no mundo afroportuguês (1441-1770). Lisboa: Edições 70, 2007.

TAMBOR TAMBORA. Montevidéu: Criatura, 2015.

THORNTON, J. A África e os africanos na formação do mundo Atlântico: 1400-1800. Rio de Janeiro: Elsevier, 2004.

Recebido em: 31 de julho de 2019 
Aceito em: 05 de dezembro de 2019 